\title{
OPEN Chemical composition of Polish propolis and its antiproliferative effect in combination with Bacopa monnieri on glioblastoma cell lines
}

\author{
Justyna Moskwa ${ }^{1}$, Sylwia K. Naliwajko ${ }^{1}$, Renata Markiewicz-Żukowska ${ }^{1 \bowtie}$, \\ Krystyna J. Gromkowska-Kępka ${ }^{1}$, Patryk Nowakowski ${ }^{1}$, Jakub W. Strawa², \\ Maria H. Borawska ${ }^{1}$, Michał Tomczyk ${ }^{2}$ \& Katarzyna Socha ${ }^{1}$
}

Propolis and Bacopa monnieri (L.) Wettst. (Brahmi) are natural products that contain many active substances and possess anticancer properties. The aim of this study was to investigate the chemical composition of Polish propolis extract (PPE) by gas chromatography-mass spectrometry (GC-MS), $B$. monnieri extracts ( $\mathrm{BcH}, \mathrm{BCS}$ ) by high performance liquid chromatography with diode array detector and mass spectrometry coupled with electrospray ionization (LC-ESI-MS) and finally determine its anti-proliferative potential combined with $\mathrm{BcH}$ and $\mathrm{BcS}$ in glioblastoma cell lines (T98G, LN-18, $\mathrm{U} 87 \mathrm{MG}$ ). The antiproliferative activity of $\mathrm{PPE}, \mathrm{BcH}, \mathrm{BcS}$ and their combination (PPE $+\mathrm{BcH}$ ) was determined by a cytotoxicity test, and DNA binding was determined by $\left[{ }^{3} \mathrm{H}\right]$-thymidine incorporation. Flavonoids and phenylpropenoids were the main components of $\mathrm{PPE}$. $\mathrm{BcH}$ and $\mathrm{BcS}$ samples were also successfully analyzed. Their main constituents were saponins such as bacoside A3, bacopaside II, $X$ and bacopasaponin $C$ and its isomer. The inhibitory effects on the viability and proliferation of the tested glioma cells observed after incubation with the combination of PPE and $\mathrm{BcH}$ were significantly stronger than the effects of these two extracts separately. These findings suggest that propolis in combination with $B$. monnieri shows promising anticancer activity for the treatment of glioblastoma. However, further studies are still required.

Glioblastoma multiforme (GBM) is a highly malignant brain tumor with an extremely poor prognosis. Standard therapies, including surgery, chemotherapy (temozolomide-TMZ), radiation therapy, hormonal therapy and targeted therapy, are frequently ineffective because numerous patients with GBM do not respond to TMZ as the tumor is resistant to treatment. The median survival time is only $14-15$ months after diagnosis ${ }^{1-3}$. The data suggest that an increasing number of cancer patients use some form of complementary and alternative medicine (35.9\%) to support therapy ${ }^{4}$. Therefore, there is a great need to understand the underlying mechanisms of tumor progression and search for new substances with anticancer potential.

Propolis is a mixture of tree and shrub resin, beeswax, pollen and secretions of bee glands with a characteristic balsamic smell and taste. The chemical composition of propolis depends on the vegetation of the geographical area it comes from, the season of the year and the breed of bees. Therefore, propolis shows different biological activities in studies by many authors. The most active compounds are flavonoids (e.g., chrysin, apigenin, pinocembrin, pinobanksin, kaempferol), aromatic acids (e.g., p-coumaric, ferulic) and esters (caffeic acid phenethyl ester, CAPE) $)^{5,6}$. Many researchers have confirmed the antioxidant, antimicrobial and anti-inflammatory activities of propolis ${ }^{7,8}$. The anticancer effects of propolis have been observed in many cancer cell lines, such as human lung cancer (A549), human prostate cancer (PC3), human myeloid leukemia (U937) and other cell lines ${ }^{9-13}$. In our previous study, we confirmed that propolis and other bee products have anti-proliferative potential in the human glioblastoma multiforme cell line U87MG $\mathrm{M}^{5,14,15}$.

Bacopa monnieri (L.) Wettst., locally known as Brahmi, is a plant species from the Plantaginaceae family that naturally occurs in wetlands and swamps. B. monnieri is one of the most important plants in Ayurveda Chinese

${ }^{1}$ Department of Bromatology, Faculty of Pharmacy with the Division of Laboratory Medicine, Medical University of Białystok, Mickiewicza 2D, 15-222 Białystok, Poland. ${ }^{2}$ Department of Pharmacognosy, Faculty of Pharmacy with the Division of Laboratory Medicine, Medical University of Białystok, Mickiewicza 2a, 15-230 Białystok, Poland. ${ }^{\square}$ email: renmar@poczta.onet.pl 
medicine. It has been used traditionally in the treatment of epilepsy and insomnia and as a sedative in anxiety disorder. The most important active compounds of this plant are triterpene saponins called bacosides ${ }^{16,17}$, alkaloids such as bramine and herpestine, flavonoid and steroid compounds ${ }^{18,19}$. In vivo studies have shown that B. monnieri extract containing $25 \%$ bacoside A causes an anxiolytic effect comparable to that of lorazepam. A frequent side effect of lorazepam is amnesia, whereas $B$. monnieri does not cause such side effects and additionally exhibits memory-improving properties ${ }^{20}$. Research has demonstrated that $B$. monnieri acts as an antioxidant and anti-inflammatory agent ${ }^{21,22}$ and increases the activity of superoxide dismutase (SOD), glutathione peroxidase (GPx) and catalase ${ }^{23}$. Furthermore, the authors confirmed its protective effect on the liver ${ }^{24}$ as well as its antimicrobial ${ }^{25}$ and antiulcer activity ${ }^{26}$. Recent research suggests that bacoside A has possible anticancer activity that may induce cell cycle arrest and apoptosis through the Notch signaling pathway in GBM in vitro ${ }^{27}$.

In the present study, the chemical composition of Polish propolis extract (PPE) was analyzed, and its antiproliferative potential when combined with $\mathrm{B}$. monnieri extracts from commercial formulations $(\mathrm{BcH}, \mathrm{BcS})$ was investigated in glioblastoma cell lines (T98G, LN-18, U87MG). This study provides new insights into the possible mechanism underlying the cytotoxic activity of PPE combined with B. monnieri in GBM cells.

\section{Results}

Chemical composition of propolis (PPE). In this study, 77 ingredients of PPE were identified. A list of these constituents is presented in Table 1 and Fig. 1. Flavonoids and chalcones $(35.13 \%)$ were the main components of PPE. The major ingredients of this group were pinobanksin (13.0\%), pinocembrin (5.7\%), chrysin (5.4\%), galangin (5.4\%) and their derivatives. Phenylpropenoids, such as (E) p-coumaric acid (6.1\%), ferulic acid (3.4\%), benzyl-(E)-ferulate (3.3\%), and benzyl p-coumarate-(E) (3.1\%), were the second most abundant group (25.72\%) Other compounds identified in PPE were present form various groups of constutuents, such as cinnamic acid esters, aliphatic acids, phenylpropenoids glycerides, aliphatic and aromatic alcohols, phenylpropenoids, sesquiterpenols, carbohydrates and other unidentified (NN) compounds.

LC-ESI-MS analysis of $B$. monnieri extracts $(\mathrm{BcH}, \mathrm{BCS})$. Among them 25 compounds were identified. Characteristic groups of compounds are both a complex of triterpene saponins-bacoside A3, A6, bacopaside II, IV, V, X, bacosaponin C with their isomers as well as a flavone of derivatives such as apigenin and luteolin. The results of the qualitative analysis of $\mathrm{BcH}$ and $\mathrm{BcS}$ are presented in Table 2 and Fig. 2.

Quantitative assessment of saponins in $\mathrm{BcH}$ and $\mathrm{BcS}$. Bacoside $\mathrm{A} 3$ and Bacosaponin $\mathrm{C}$ were quantified using HPLC method in a homogenized sample of commercial formulation ( $\mathrm{BcS}$ and $\mathrm{BcH})$ from $B$. monnieri. BcS contains $7.92 \pm 0.25 \mathrm{mg}$ of bacoside A3 and $10.69 \pm 0.12 \mathrm{mg}$ of bacopasaponin $\mathrm{C}$ in $1 \mathrm{~g}$ of extract. $\mathrm{BcH}$ contains $27.77 \pm 0.09 \mathrm{mg}$ of bacoside $\mathrm{A} 3$ and $31.57 \pm 0.07 \mathrm{mg}$ of bacopasaponin $\mathrm{C}$ in $1 \mathrm{~g}$ of extract. The results of the quantitative analysis of $\mathrm{BcH}$ and $\mathrm{BcS}$ are presented in Table 3.

Total phenolic content (TPC). The total phenolic content of $\mathrm{PPE}, \mathrm{BcH}$, and $\mathrm{BcS}$ was determined using the Folin-Ciocalteu assay and found to be $137.19 \pm 3.96,14.80 \pm 0.18$, and $14.57 \pm 0.21 \mathrm{mg} \mathrm{GAE} / \mathrm{g}$, respectively (Table 4).

Cytotoxic activity. In this study, the cytotoxic effect of $\mathrm{BcH}, \mathrm{BcS}(10-100 \mu \mathrm{g} / \mathrm{mL})$ alone and $\mathrm{BcH}(10-$ $100 \mu \mathrm{g} / \mathrm{mL})$ in combination with PPE30 $(30 \mu \mathrm{g} / \mathrm{mL})$ was examined in T98G, LN-18 and U87MG cells. A timedependent decrease was found in the cell viability of all tested glioma cell lines (Fig. 3a-c, Fig. 4). After $72 \mathrm{~h}$ of treatment with $\mathrm{BcH}$, significant $(p<0.05)$ reductions in viability were observed at concentrations $\geq 5 \mu \mathrm{g} / \mathrm{mL}$ for T98G and U87MG cells and $\geq 10 \mu \mathrm{g} / \mathrm{mL}$ for LN-18 cells. The estimated $\mathrm{IC}_{50}$ values for T98G, U87MG and LN-18 were 35.9, 50.5 and $51.7 \mu \mathrm{g} / \mathrm{mL}$, respectively. After $72 \mathrm{~h}$ of treatment with the BcS extract, significant $(p<0.05)$ reductions in viability were found at all concentrations for the studied glioma cell lines. The estimated $\mathrm{IC}_{50}$ values for T98G, U87MG and LN-18 cells were $40.9,122.0$ and $154.8 \mu \mathrm{g} / \mathrm{mL}$, respectively. BcH extract was used for further study. Moreover, the quantitative determination of the composition of B. monnieri extracts showed a higher content of both, Bacoside $\mathrm{A} 3$ and Bacosaponin $\mathrm{C}$ in $\mathrm{BcH}$ than in $\mathrm{BcS}$ extract, which may explain the stronger cytotoxic effect of the $\mathrm{BcH}$ extract against glioblastoma multiforme cells. The cytotoxic effect of the combination of PPE and BcH extracts on T98G, U87MG and LN-18 cells was significantly higher $(p<0.05)$ than that of PPE used separately: after $24 \mathrm{~h}$ at concentrations of $\mathrm{BcH} \geq 50 \mu \mathrm{g} / \mathrm{mL}$ for T98G and LN-18 and $\geq 100 \mu \mathrm{g} /$ $\mathrm{mL}$ for U87MG; after $48 \mathrm{~h}$ at concentrations of $\mathrm{BcH} \geq 50 \mu \mathrm{g} / \mathrm{mL}$ for all tested glioma cell lines and after $72 \mathrm{~h}$ at concentrations of $\mathrm{BcH} \geq 5 \mu \mathrm{g} / \mathrm{mL}$ for T98G and $\geq 50 \mu \mathrm{g} / \mathrm{mL}$ for LN-18 and U87MG (Fig. 4).

The effect on DNA synthesis in glioblastoma cell lines. To examine the influence of the tested extracts and their combination on the DNA synthesis and proliferation of glioblastoma cells, the incorporation of $\left[{ }^{3} \mathrm{H}\right]$-thymidine was evaluated. In this study, strong significant inhibition of DNA synthesis in T98G, LN-18, and U87MG cells was found after $48 \mathrm{~h}$ of incubation with PPE30 $(66.8 \pm 3.2,36.8 \pm 6.1$, and $45.6 \pm 2.9 \%$ of the control, respectively) and BcH50 (47.0 $\pm 6.5,43.0 \pm 4.2$, and $42.2 \pm 9.0 \%$ of the control, respectively) (Fig. 5). The combination of PPE30 with BcH50 significantly inhibited DNA synthesis in the tested cells (less than $13 \%$ of the control) (Fig. 5).

Cell cycle. The effect of PPE30, BcH50 and their combination on the cycle of T98G, LN-18 and U87MG cells after $48 \mathrm{~h}$ of incubation is presented in Fig. 6. Cell nuclei were stained, and the percentage of cells in specific cell cycle phases was calculated. Our data revealed that treatment with PPE30 extract caused increased cell cycle 


\begin{tabular}{|c|c|c|c|c|}
\hline Components, TMS derivative & Rt, min & LTPRI $^{\mathrm{Exp}}$ & LTPRI $^{\mathrm{lit}}$ & Relative composition (\%) \\
\hline Benzyl alcohol & 18.66 & 1157 & 1156 & 0.5 \\
\hline 2-Phenyl ethanol & 21.95 & 1229 & 1227 & 0.4 \\
\hline Benzoic acid & 22.85 & 1249 & 1248 & 4.8 \\
\hline Glycerol & 24.83 & 1293 & 1293 & 1.3 \\
\hline Vaniline & 35.05 & 1541 & 1542 & 0.7 \\
\hline Cinnamic acid & 35.32 & 1547 & 1546 & 0.4 \\
\hline 4-Hydroxybenzoic acid & 38.63 & 1634 & 1636 & 0.4 \\
\hline 6-Hydroxy- $\beta$-caryophyllene & 40.41 & 1683 & 1682 & 0.6 \\
\hline n.n. $(44,73,281,75)$ & 41.80 & 1721 & - & 0.2 \\
\hline n.n. $(130,73,90,44)$ & 41.89 & 1724 & - & 0.4 \\
\hline$\gamma$-Eudesmol & 42.63 & 1745 & 1740 & 0.8 \\
\hline$\beta$-Eudesmol & 42.93 & 1754 & 1751 & 0.6 \\
\hline Benzyl benzoate & 43.40 & 1768 & 1765 & 0.3 \\
\hline (Z) $p$-Coumaric acid & 44.55 & 1801 & 1798 & 0.2 \\
\hline n.n. $(73,204,147,143)$ & 45.49 & 1829 & - & 0.3 \\
\hline a-Fructofuranose & 45.92 & 1842 & 1845 & 0.8 \\
\hline$\beta$-Fructofuranose & 46.23 & 1852 & 1854 & 3.6 \\
\hline a-Mannofuranose & 47.02 & 1876 & 1874 & 0.7 \\
\hline a-Glucopyranose & 48.80 & 1930 & 1929 & 1.8 \\
\hline (E) $p$-Coumaric acid & 49.39 & 1949 & 1949 & 6.1 \\
\hline n.n. $(44,73,281,75)$ & 50.35 & 1979 & - & 0.2 \\
\hline n.n. $(130,73,90,44)$ & 50.92 & 1997 & - & 0.2 \\
\hline$\beta$-Glucopyranose & 51.93 & 2029 & 2032 & 1.8 \\
\hline 3,4-Dimethoxycinnamic acid & 52.13 & 2036 & 2034 & 0.5 \\
\hline Hexadecanoic acid & 52.56 & 2051 & 2052 & 0.4 \\
\hline Isoferulic acid & 53.80 & 2092 & 2088 & 1.1 \\
\hline Ferulic acid & 54.18 & 2104 & 2104 & 3.4 \\
\hline (E)-Caffeic acid & 55.60 & 2153 & 2156 & 2.4 \\
\hline 2-Methyl-2-butenyl-(E)-p-coumarate & 57.17 & 2207 & 2203 & 0.3 \\
\hline 3-Methyl-2-butenyl (E)-p-coumarate & 57.35 & 2214 & 2216 & 0.3 \\
\hline Oleic acid & 57.56 & 2222 & 2222 & 0.6 \\
\hline n.n. $(73,147,156,233,75)$ & 57.89 & 2234 & - & 1.0 \\
\hline Stearic acid & 58.30 & 2249 & 2249 & 0.3 \\
\hline 2(3)-Methylbutanyl-(E)-caffeate & 60.28 & 2353 & 2358 & 0.4 \\
\hline 3-Methyl-3-butenyl-(E)-caffeate & 61.61 & 2368 & 2367 & 1.8 \\
\hline 2-Methyl-2-butenyl-(E)-caffeate & 62.75 & 2414 & 2413 & 0.5 \\
\hline 3-Methyl-2-butenyl-(E)-caffeate & 63.07 & 2427 & 2424 & 2.1 \\
\hline Eicosanoic acid & 63.63 & 2448 & 2447 & 0.2 \\
\hline Pinocembrin, mono-TMS & 64.08 & 2466 & 2461 & 0.6 \\
\hline $2^{\prime}, 6^{\prime}, \alpha$-Trihydroxy-4'-methoxychalcone & 64.87 & 2497 & 2492 & 0.5 \\
\hline Benzyl $p$-Coumarate- $(E)$ & 65.45 & 2520 & 2515 & 3.1 \\
\hline Pinocembrin chalcone & 66.06 & 2544 & 2541 & 0.2 \\
\hline Pinocembrin & 66.26 & 2551 & 2552 & 4.9 \\
\hline n.n. $(192,73,297,311)$ & 67.17 & 2589 & - & 0.6 \\
\hline Pinobanksin & 67.73 & 2606 & 2611 & 4.7 \\
\hline $\mathrm{NN}(73,297,253)$ & 68.34 & 2619 & - & 1.1 \\
\hline Chrysin, mono-TMS & 68.90 & 2662 & 2655 & 0.9 \\
\hline Benzyl-(E)-ferulate & 69.44 & 2685 & 2680 & 3.3 \\
\hline Pinobanksin 3-acetate & 69.78 & 2700 & 2695 & 7.4 \\
\hline n.n. $(73,361,217)$ & 70.00 & 2709 & - & 0.8 \\
\hline Benzyl (E)-caffeate & 70.47 & 2729 & 2723 & 2.2 \\
\hline Chrysin, di-TMS & 71.01 & 2752 & 2746 & 4.5 \\
\hline 5,7-Dihydroxy-3-methoxyflavanone, di-TMS & 71.24 & 2762 & 2760 & 0.4 \\
\hline Galangin, tri-TMS & 71.49 & 2773 & 2769 & 5.4 \\
\hline Pinobanksin 3-isobutanoate & 72.07 & 2794 & 2791 & 0.7 \\
\hline 2-Phenylethyl (E)-caffeate, CAPE & 72.36 & 2805 & 2805 & 2.3 \\
\hline
\end{tabular}




\begin{tabular}{|c|c|c|c|c|}
\hline Components, TMS derivative & Rt, min & LTPRI $^{\mathrm{Exp}}$ & LTPRI $^{\text {lit }}$ & Relative composition (\%) \\
\hline Isosakuranetin, 5,7-dihydroxy-4'-methoxyflavanone-TMS & 72.70 & 2823 & 2820 & 0.6 \\
\hline Tetracosanoic acid & 73.11 & 2845 & 2844 & 1.7 \\
\hline Pinobanksin 3-n-butanoate & 73.29 & 2853 & 2849 & 0.2 \\
\hline Sakuranetin chalcone & 73.74 & 2873 & 2870 & 0.3 \\
\hline Sakuranetin & 73.96 & 2884 & 2880 & 2.2 \\
\hline Unidentified chalcone $(280,73)$ & 74.77 & 2921 & 2918 & 0.1 \\
\hline n.n. $(73,44,75,189)$ & 75.13 & 2937 & - & 0.4 \\
\hline n.n. $(73,300,147,305)$ & 75.72 & 2964 & - & 0.2 \\
\hline n.n. $(44,73,207)$ & 75.85 & 2975 & - & 0.1 \\
\hline n.n. $(117,115,249,73)$ & 76.17 & 2985 & - & 0.2 \\
\hline Acacetin & 76.55 & 2998 & 2991 & 0.2 \\
\hline n.n. $(386,73,297,135)$ & 76.98 & 3023 & - & 0.3 \\
\hline 5,7,4'-Trihydroxy-3'-methoxyflavanone & 77.59 & 3053 & 3050 & 0.6 \\
\hline n.n. $(83,413,111)$ & 78.01 & 3073 & - & 1.1 \\
\hline Kaempferol & 78.89 & 3115 & 3114 & 0.8 \\
\hline 6-Hydroxy- $\beta$-caryophyllene $p$-coumarate & 79.48 & 3145 & 3136 & 0.7 \\
\hline n.n. $(472,73,228,474)$ & 79.84 & 3163 & - & 0.4 \\
\hline 14-Hydroxy- $\beta$-caryophyllene, $p$-coumarate & 80.13 & 3177 & 3165 & 0.4 \\
\hline n.n. $(73,103,301,147)$ & 81.52 & 3250 & - & 1.4 \\
\hline 1,3-di-p-coumaroyl glycerol, tri-TMS & 93.36 & 3865 & 3870 & 1.2 \\
\hline 2-Acetyl-1,3-di-p-coumaroyl glycerol, TMS & 95.50 & 3963 & 3960 & 1.0 \\
\hline
\end{tabular}

Table 1. Chemical composition of the PPE. n.n.-not identified; LTPRI-linear temperature-programmed retention index system.



Figure 1. GC-MS of ethanol extract of propolis (PPE). Main components-1: Benzoic acid, 2: (E)-p-Coumaric acid, 3: Ferulic acid, 4: (E)-Caffeic acid, 5: 3-Methyl-2-butenyl-(E)-caffeate, 6: Benzyl p-Coumarate (E), 7: Pinocembrin, 8: Pinobanksin, 9: Benzyl-(E)-ferulate, 10: Pinobanksin 3-acetate, 11: Benzyl (E)-caffeate, 12: Chrysin, 13: Galangin, 14: CAPE.

arrest (T98G cells: at subG1 phase by $11 \%$ and at S phase by $12 \%$; LN-18 cells: at subG1 phase by $2 \%$ and at S phase by $6 \%$; and U87MG cells: at subG1 phase by $2 \%$, at S phase by $9 \%$ and at G2/M phase by $4 \%$ compared to the control). In fact, after treatment with $\mathrm{BcH} 50$, the percentage of cells in subG1 phase increased by approximately $8 \%(\mathrm{LN}-18)$ and $26 \%$ (U87MG), the percentage of cells in G1 phase increased by approximately $16 \%$ (T98G), the percentage of cells in S phase increased by approximately 15\% (LN-18) and 4\% (U87MG), and the 


\begin{tabular}{|c|c|c|c|c|}
\hline No & $\begin{array}{l}\mathrm{Rt} \\
\min \end{array}$ & $\begin{array}{l}\text { Negative mode } \\
\mathrm{m} / \mathrm{z}\end{array}$ & $\begin{array}{l}\text { Positive mode } \\
m / z\end{array}$ & Tentatively identified compound \\
\hline 1 & 3.00 & $177,257,369$ & - & Bacopaside A derivatives \\
\hline 2 & 3.81 & $1101, \mathbf{1 1 3 7}, 1147$ & $455,487,617,779,911$ & j diglc-arab-acetylpentoside \\
\hline 3 & 3.96 & 133,285 & 287 & Luteolin $_{(\mathrm{s})}$ \\
\hline 4 & 4.70 & $877,1071,1107,1117$ & $455,909,1095$ & j diglc-arab-acetylpentoside \\
\hline 5 & 5.92 & 269 & 271 & Apigenin $_{(\mathrm{s})}$ \\
\hline 6 & 8.49 & $795,927, \mathbf{9 6 3}, 973$ & $455,617,779,911$ & Bacoside $\mathrm{A} 3_{(\mathrm{s})}$ \\
\hline 7 & 8.81 & $795,927,963,973$ & $455,617,779,911$ & Bacopaside $\mathrm{II}_{(\mathrm{s})}$ \\
\hline 8 & 10.53 & $897, \mathbf{9 3 3}, 943,993$ & $455,587,749,881,921,944$ & Bacopaside $\mathrm{X}_{(\mathrm{s})}$ \\
\hline 9 & 11.15 & $897, \mathbf{9 3 3}, 943$ & $473,605,767,921$ & Bacopasaponin $\mathrm{C}_{(\mathrm{s})}$ \\
\hline 10 & 11.51 & $897, \mathbf{9 3 3}, 943$ & $473,605,767$ & Bacopasaponin C isomer $_{(\mathrm{s})}$ \\
\hline 11 & 12.02 & n.d & 274 & Imino diethanol \\
\hline 12 & 12.30 & $795, \mathbf{8 3 1}, 1149$ & $455,617,779,797$ & Unknown \\
\hline 13 & 13.53 & $765, \mathbf{8 0 1}, 811$ & $\mathbf{4 5 5}, 587,749$ & Bacopaside IV or V \\
\hline 14 & 14.12 & 845 & $473,605,767$ & Bacopasaponin D \\
\hline 15 & 14.60 & n.d & 455,635 & Unknown \\
\hline 16 & 14.81 & $963, \mathbf{1 0 5 9}, 1095$ & $455,605,737$ & Bacoside derivatives \\
\hline 17 & 16.61 & n.d & $473, \mathbf{5 8 7}$ & Unknown \\
\hline 18 & 16.72 & n.d & 605 & Unknown \\
\hline 19 & 17.76 & 909, 945 & $455,617,911$ & Bacoside A6 isomer \\
\hline 20 & 18.15 & 909, 945 & $455,617,911$ & Bacoside A6 isomer \\
\hline 21 & 18.23 & $453,488, \mathbf{9 1 5}, 925$ & 881 & Deoxy-p-ara-glc-ara isomer \\
\hline 22 & 18.54 & n.d & 445,490 & Unknown \\
\hline 23 & 18.72 & $453,488, \mathbf{9 1 5}, 925$ & 881 & Deoxy-p-ara-glc-ara isomer \\
\hline 24 & 21.97 & n.d & 386,455 & Unknown \\
\hline 25 & 22.23 & n.d & 386,473 & Unknown \\
\hline
\end{tabular}

Table 2. Qualitative LC-MS analysis of $\mathrm{BcH}$ and $\mathrm{BcS}$. j-jujubogenin; p-pseudojujubogenin ara-arabinose; glcglucose; (s) - reference substance; bolded-peak with the highest abundance; n.d. not detected.



Figure 2. The qualitative assessment of commercial Bacopa monnieri L. extracts (BcH, BcS) using LC-ESI-MS in positive mode ionisation. 


\begin{tabular}{|l|l|l|}
\hline Extract & $\begin{array}{l}\text { Bacoside A3 } \\
\text { (mg/g extract) } \\
\text { Mean } \pm \text { SD }\end{array}$ & $\begin{array}{l}\text { Bacosaponin C } \\
\text { (mg/g extract) } \\
\text { Mean } \pm \text { SD }\end{array}$ \\
\hline $\mathrm{BcH}$ & $27.77 \pm 0.09$ & $31.57 \pm 0.07$ \\
\hline $\mathrm{BcS}$ & $7.92 \pm 0.25$ & $10.69 \pm 0.12$ \\
\hline
\end{tabular}

Table 3. Qualitative analysis of $\mathrm{BcH}$ and $\mathrm{BcS}$.

\begin{tabular}{|l|l|}
\hline Extracts & $\begin{array}{l}\text { TPC }(\mathrm{mg} \mathrm{GAE} / \mathrm{g}) \\
\text { Mean } \pm \text { SD }\end{array}$ \\
\hline $\mathrm{PPE}$ & $137.19 \pm 3.96$ \\
\hline $\mathrm{BcH}$ & $14.80 \pm 0.18$ \\
\hline $\mathrm{BcS}$ & $14.57 \pm 0.21$ \\
\hline
\end{tabular}

Table 4. Total phenolic content (TPC) of the PPE, BcH and BcS. TPC-milligrams of gallic acid equivalent [GAE] per gram of dry extract.

percentage of cells in G2/M phases increased by approximately $13 \%$ (LN-18) and $8 \%$ (U87MG) compared to the control. The combination of the studied extracts impacted the cell cycle by increasing the percentage of cells arrested at subG1 phase by approximately $3 \%$ (LN-18) and 16\% (U87MG), the percentage of cells arrested at G1 phase by approximately $8 \%$ (T98G), the percentage of cells arrested at S phase by approximately $24 \%$ (LN-18), and the percentage of cells arrested at G2/M by approximately $9 \%(\mathrm{LN}-18)$ and $3 \%$ (U87MG) compared to the control.

Apoptosis quantification by Annexin V/PI staining. Annexin V and PI staining was used to assess the impact of treatment with the studied extracts and their combination on glioblastoma cell apoptosis (Fig. 7). Apoptosis quantification indicated that PPE30 caused an increase in the quantity of T98G, LN-18 and U87MG cells in early apoptosis (lower right quadrant) by approximately $14 \%, 3 \%$ and $9 \%$, respectively, compared to the control. The effect of $\mathrm{BcH} 50$ on glioblastoma cells was based on the induction of late apoptosis and necrosis via an increased percentage of T98G, LN-18 and U87MG cells in the upper quadrant (approximately 61\%, 56\% and $44 \%$, respectively). The combination of PPE30 and $\mathrm{BcH} 50$ exerts a partial effect on the induction of early apoptosis and late apoptosis/necrosis in the tested cell lines. The extract blend increased the ratio of T98G, LN-18 and U87MG cells in early apoptosis by approximately $8 \%, 17 \%$ and $1 \%$, respectively. Moreover, the number of cells in late apoptosis/necrosis increased by $35 \%$ and $17 \%$ in the T98G and U87MG cell lines, respectively.

\section{Discussion}

Glioblastoma multiforme (GBM) belongs to a group of the most lethal human cancers. Despite medical developments and the use of new cancer therapies and drugs, the mortality of GBM patients still remains high. Therefore, it is extremely important to continue to search for new compounds (also of natural origin) that could represent the origin of an anticancer drug or therapy. According to a European study of 956 patients carried out in 14 countries, as many as $50 \%$ of patients with brain tumors have used complementary and alternative medicine ${ }^{4}$. Thus, in this study, we aimed to evaluate the anticancer effect of Polish propolis extract (PPE) combined with $B$. monnieri extracts obtained from commercial products $(\mathrm{BcH}$ and $\mathrm{BcS})$. According to the literature, the combined effect of PPE with bacopa has not been investigated thus far. This study provides, for the first time, evidence for the use of the combination in glioblastoma cell lines.

Propolis is a well-known product that contains many active substances that possess anticancer properties. However, its chemical composition and the number of active components might vary greatly depending on its location and other factors. In our study, the PPE sample was found to contain the flavonoids (Fig. 1) pinobanksin, pinobanksin 3-O-acetate, chrysin, and galangin and the phenolic acids $p$-coumaric, ferulic, caffeic and cinnamic acid esters. This compound is characteristic of propolis originating from the bud exudates of Populus nigra ${ }^{6,28}$. Other authors also proved the presence of these constituents in Polish propolis samples ${ }^{6,29}$. In addition, according to another study, the high amount of $p$-coumaric acid and ferulic acid as well as their esters (also found in our PPE sample) was very typical of the bud of Populus tremula ${ }^{30,31}$. The high content of phenolic compounds of PPE was confirmed in the TPC determination, where it was $137.19 \pm 3.96 \mathrm{mg}$ GAE/g. Other authors showed a similar or lower TPC in Polish propolis. The values ranged from 14.59 to $150.80 \mathrm{mg} \mathrm{GAE} / \mathrm{g}$ and depended on the extraction method ${ }^{32}$. Due to the presence of a large amount of active substances, propolis has strong anticancer activity, which has been confirmed in many studies. Propolis from Brazil showed a strong inhibitory effect on cell growth in glioblastoma (U251 and U343) and fibroblast cell lines (MRC5) but had no effects on apoptosis, demonstrating a cytostatic effect ${ }^{33}$.

Apoptosis quantification indicated that PPE caused an increase in the quantity of T98G, LN-18 and U87MG cells in early apoptosis (approximately 14\%,3\% and 9\% compared to the control, respectively). On the other hand, according to Szliszka et al. ${ }^{34}$, propolis from Poland $(50 \mu \mathrm{g} / \mathrm{mL})$ caused an increase in the percentage of apoptotic cells (to 71.10\%) in HeLa cells resistant to tumor necrosis factor-related apoptosis-inducing ligand (TRAIL). Furthermore, apigenin and CAPE may be the compounds responsible for this activity ${ }^{11,35}$. In our previous 


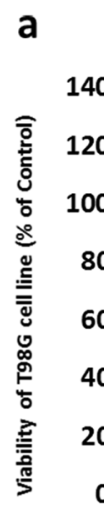



T98G

DCS

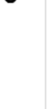



24H

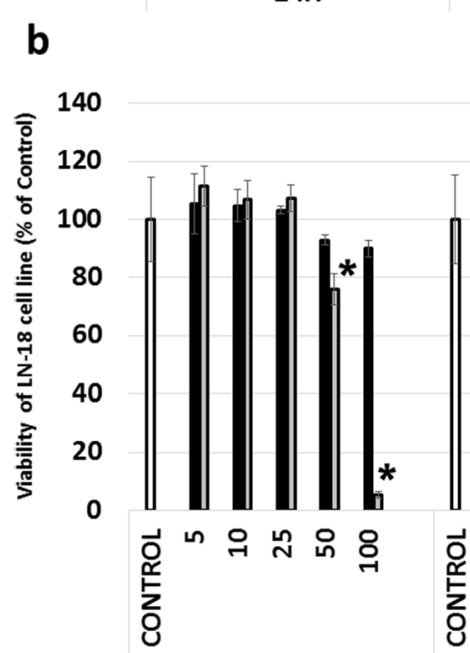

$24 \mathrm{H}$

$48 \mathrm{H}$

LN-18
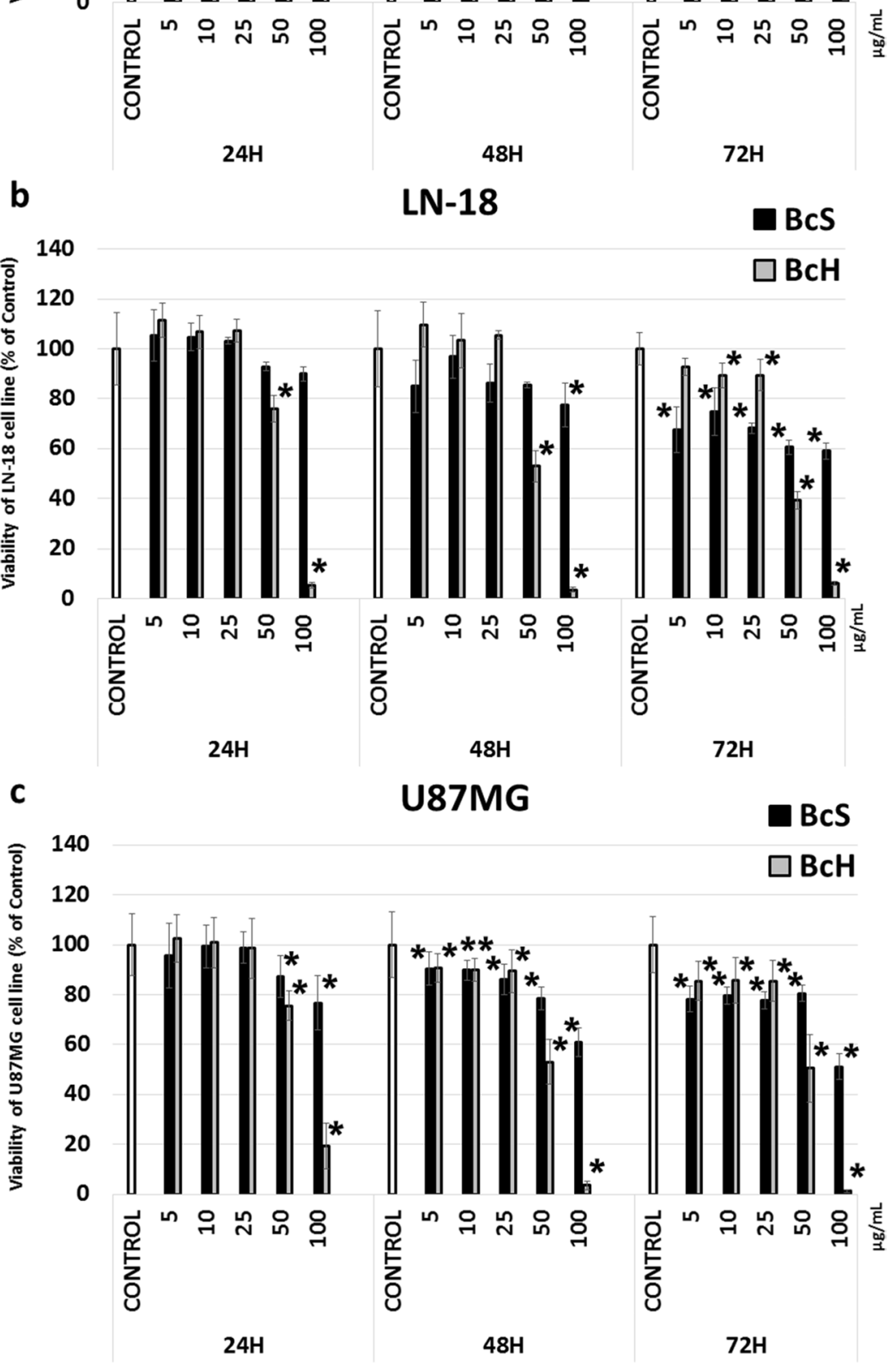

Figure 3. Viability of T98G (a), LN-18 (b) and U87MG (c) cells after 24, 48 and $72 \mathrm{~h}$ of incubation with BcH and $\mathrm{BcS}$ extracts $(5,10,25,50,100 \mu \mathrm{g} / \mathrm{mL})$. The results are presented as a percentage of control. All statistical analyses were performed using Student's $t$ test (significant changes: ${ }^{*} p<0.05$ vs control). 
60

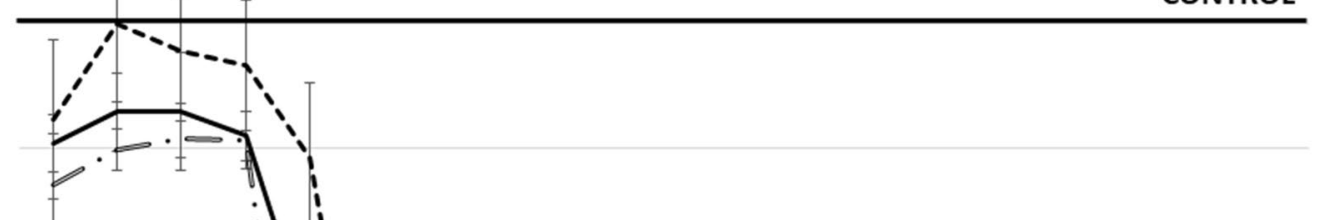

40

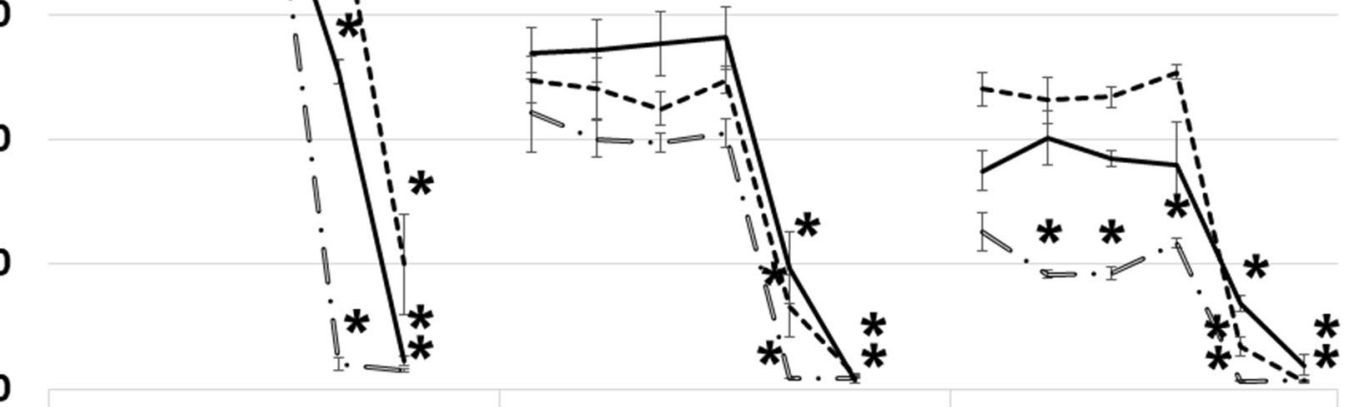

0

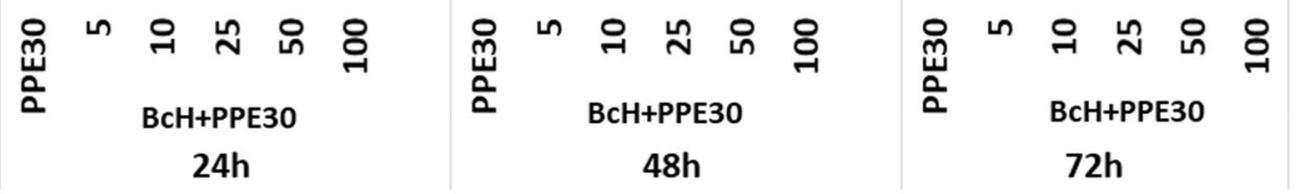

Figure 4. Viability of T98G, LN-18 and U87MG cells after $48 \mathrm{~h}$ of incubation with PPE30 $(30 \mu \mathrm{g} / \mathrm{mL})$ and $\mathrm{BcH}(5,10,25,50,100 \mu \mathrm{g} / \mathrm{mL})$ combined with PPE30. The results are presented as a percentage of control. All statistical analyses were performed using Student's $t$ test (significant changes: ${ }^{\star} p<0.05$ PPE30 vs BcH + PPE30).

study, PPE was found to present cytotoxic properties and cooperate with temozolomide (TMZ), synergistically enhancing its growth-inhibiting activity against the glioblastoma U87MG cell line through the reduced activity of nuclear factor kappa-light-chain-enhancer of activated B cells $(\mathrm{NF}-\kappa \mathrm{B})^{14}$.

The results of the cell cycle assay showed that treatment with PPE30 caused cell cycle arrest of T98G cells at the subG1 phase (11\%) and S phase (12\%), cell cycle arrest of LN-18 cells at the subG1 phase (2\%) and S phase (6\%), and cell cycle arrest of U87MG cells at the subG1 phase (2\%), S phase (9\%) and G2/M phase (4\%) compared to the control. Studies on the effects of Lebanese propolis extracts on cell lines have also shown antiproliferative and cytotoxic effects, which are observed as an increase in the percentage of cells in the subG1 phase of the cell cycle. The percentage of Jurkat cells in subG1 increased after $24 \mathrm{~h}$ of incubation with both crude extract and hexane fractions. A significant increase in the percentage of cells in the subG1 phase was also observed in glioblastoma cells (U251) and breast adenocarcinoma (MDA-MB-231) after $24 \mathrm{~h}$ of exposure to the hexane fraction ${ }^{36}$.

The main goal of our research was to determine whether the combination of PPE and $\mathrm{BcH}$ and BcS would enhance the antitumor effect or, on the contrary, cause negative interactions and reverse effects. The reason that $B$. monnieri extract was used in our investigation was the significant amount of active substances, such as bacosides in this plant. A quality control for quantitative and qualitative analysis of $\mathrm{BcH}$ and $\mathrm{BcS}$ was proposed to analyze food supplements using liquid chromatography with coupled with mass spectrometer (LC-MS). The chemical composition of $\mathrm{BcH}$ and $\mathrm{BcS}$ was characterized by the dominance of the triterpene saponin complex. They are represented by jujubogenin derivatives, including bacoside A3 in both samples, as well as bacopasaponin A, E-G, and bacopaside III-IV. The second group of the same type of compounds were pseudojujubogenin derivatives such as bacopasaponin C, bacopaside II, and V. Two common flavones, luteolin and apigenin, as well as imino derivatives were also present in all samples of B. monnier $i^{37}$.

Bacosides have a multidirectional pharmacological action. According to Ayurvedic medicine, the presence of bacoside A and bacoside B enhances memory. Bacosides inhibit lipoxygenase activity, scavenge free radicals and protect the neural cells of the prefrontal cortex, hippocampus, and striatum against cytotoxicity and DNA damage implicated in Alzheimer's disease. Furthermore, bacosides increase glutathione peroxidase, chelate iron and enhance nitric oxide-mediated cerebral vasodilation, leading to improvements in the total memory score ${ }^{38}$.

A prior study showed that $B$. monnieri plant extract and bacoside A enhance CaMK2A and activate its phosphorylation (pCaMK2A) in glioblastoma cells. Furthermore, pCaMK2A triggers an increase in high calcium release from the endoplasmic reticulum, causing tumor cell death. John et al. ${ }^{39}$ suggested that bacoside A has excellent brain availability through the oral route; hence, it should be proposed as a potential treatment for GBM. Other authors showed that B. monnieri (dichloromethane fraction) has anticancer potential against 


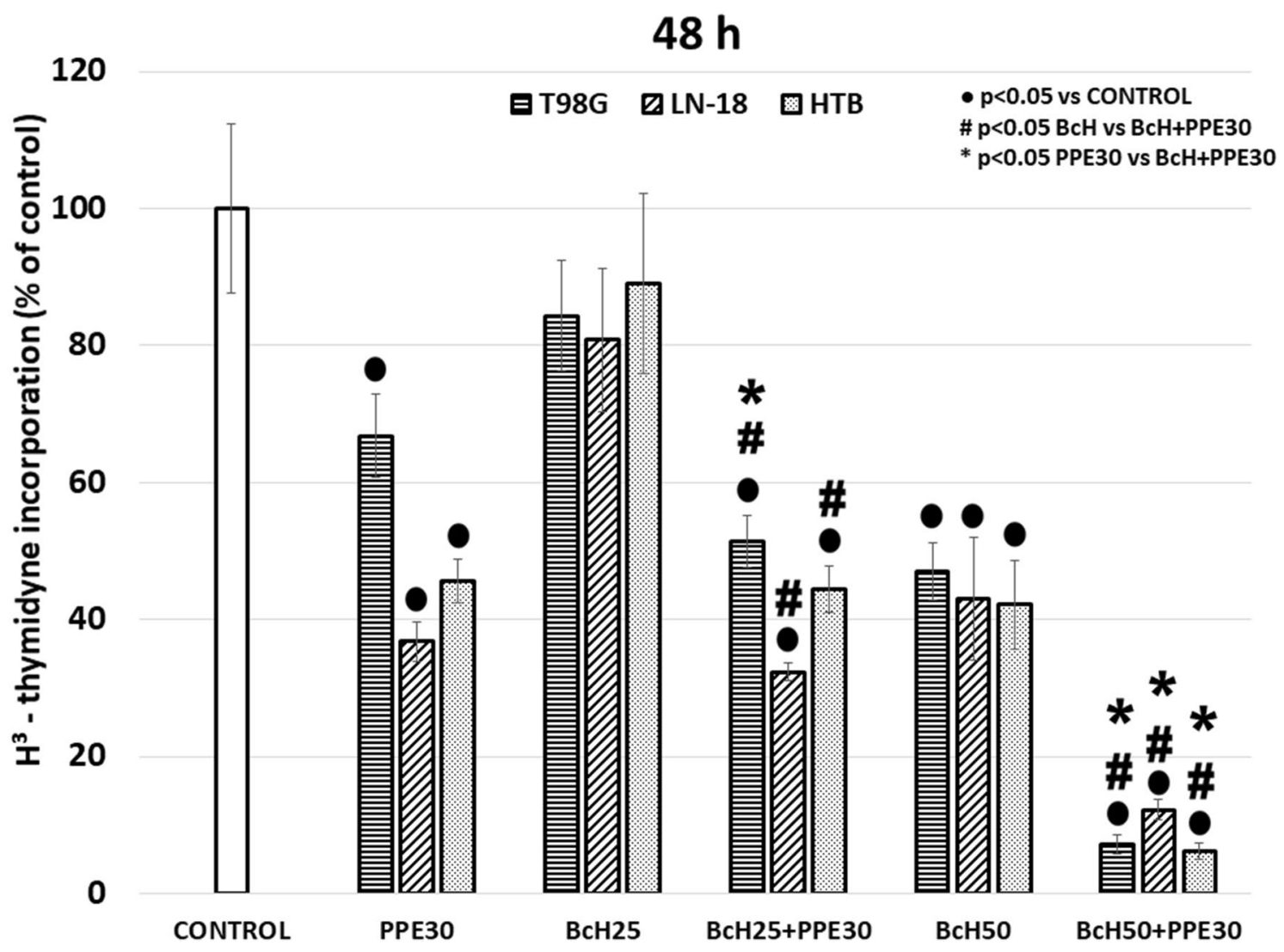

Figure 5. $\left[{ }^{3} \mathrm{H}\right]$-thymidine incorporation on T98G, LN-18 and U87MG cells after $48 \mathrm{~h}$ of incubation with PPE30 $(30 \mu \mathrm{g} / \mathrm{mL}), \mathrm{BcH}(25,50 \mu \mathrm{g} / \mathrm{mL})$ and combination PPE30 with $\mathrm{BcH}$. The results are presented as a percentage of control. All statistical analyses were performed using Student's $t$ test (significant changes: Op $<0.05$ vs control, \# $\mathrm{p}<0.05 \mathrm{BcH} v s \mathrm{BcH}+\mathrm{PPE} 30,{ }^{*} p<0.05$ PPE30 vs $\left.\mathrm{BcH}+\mathrm{PPE} 30\right)$.

various human cancer cell lines-colon (HT29, Colo320, and Caco2), lung (A549), cervix (HeLa, SiHa), and breast (MCF-7, MDAMB-231) ( $\mathrm{IC}_{50} 41.0-60.0 \mu \mathrm{g} / \mathrm{mL}$ after $72 \mathrm{~h}$ ) - and in vivo in Ehrlich ascites carcinoma (EAC)-treated mice (at a dose of $40 \mathrm{mg} / \mathrm{kg}$ body weight). It has also been confirmed by in silico screening that the anticancer activity of $B$. monnieri may be due to the presence of bacosides and cucurbitacin ${ }^{40}$. Other studies have demonstrated that bacopaside II (a bacopa component) inhibits colon cancer cell growth at $\geq 20 \mu \mathrm{M}$ for HT-29 cells and $\geq 15 \mu \mathrm{M}$ for SW480, SW620 and HCT116 cells by inducing cell cycle arrest and apoptosis ${ }^{41}$.

In fact, after treatment with BcH50, the percentage of cells in subG1 increased by approximately $8 \%$ (LN-18) and $26 \%$ (U87MG), the percentage of cells in G1 phase increased by approximately $16 \%$ (T98G), the percentage of cells in S phase increased by approximately 15\% (LN-18) and 4\% (U87MG), and the percentage of cells in the G2/M phases increased by approximately $13 \%$ (LN-18) and $8 \%$ (U87MG) compared to the control. Smith et al. ${ }^{41}$ tested bacopaside II on SW620, SW480, HCT116 and HT-29 colon cancer cells. Their results showed that treatment with bacopaside II for SW620, SW480 and HCT116 cells resulted in an increase in the percentage of cells in G2/M phase and a concomitant decrease in G1 phase. In contrast, for HT-29, bacopaside II caused an increase in G0/G1 phase and a decrease in S phase, while a higher concentration of bacopaside II caused an increase in cells in G2/M phase and a concomitant decrease in cells in G0/G1 phase. These results suggest that cell death occurs after the use of this compound and is consistent with the observed reduction in cell growth ${ }^{41}$. The results of the research suggest that the main mechanism of $B$. monnieri is probably based on macropinocytosis, so the effect of these extracts is not observed upon examination of the cell cycle, despite a pronounced cytotoxic effect on glioblastoma cells. Some cancer lines after B. monnieri treatment have shown that the DNA fragmentation process is initiated, but the main mechanism of cell death is cell lysis, which occurs as a result of a combination of acute macropinocytotic overstress and anoiki necrosis, as demonstrated by John et al. ${ }^{39}$ in their investigation. Glioblastoma cells are vulnerable to high calcium-induced macropinocytotic hydrostatic stress. B. monnieri plant extract/bacoside A enhances calcium/calmodulin-dependent protein kinase type II subunit alpha (CaMK2A) and activates CaMK2A phosphorylation (pCaMK2A) in glioblastoma cells, and pCaMK2A triggers high calcium release from the endoplasmic reticulum, causing macropinocytotic and membrane hydrostatic stress-induced tumor cell death. Our studies revealed that the effect of $\mathrm{BcH} 50$ on glioblastoma cells was based on the induction of late apoptosis and necrosis via an increased percentage of T98G, LN-18 and U87MG cells (approximately 61\%, $56 \%$ and $44 \%$, respectively). Examination of bacopaside II in colon cancer cell lines (HT-29, SW480, SW620 and HCT116 cells) induced an increase in cell apoptosis. For HT-29 cells, bacopaside II induced a marked increase 

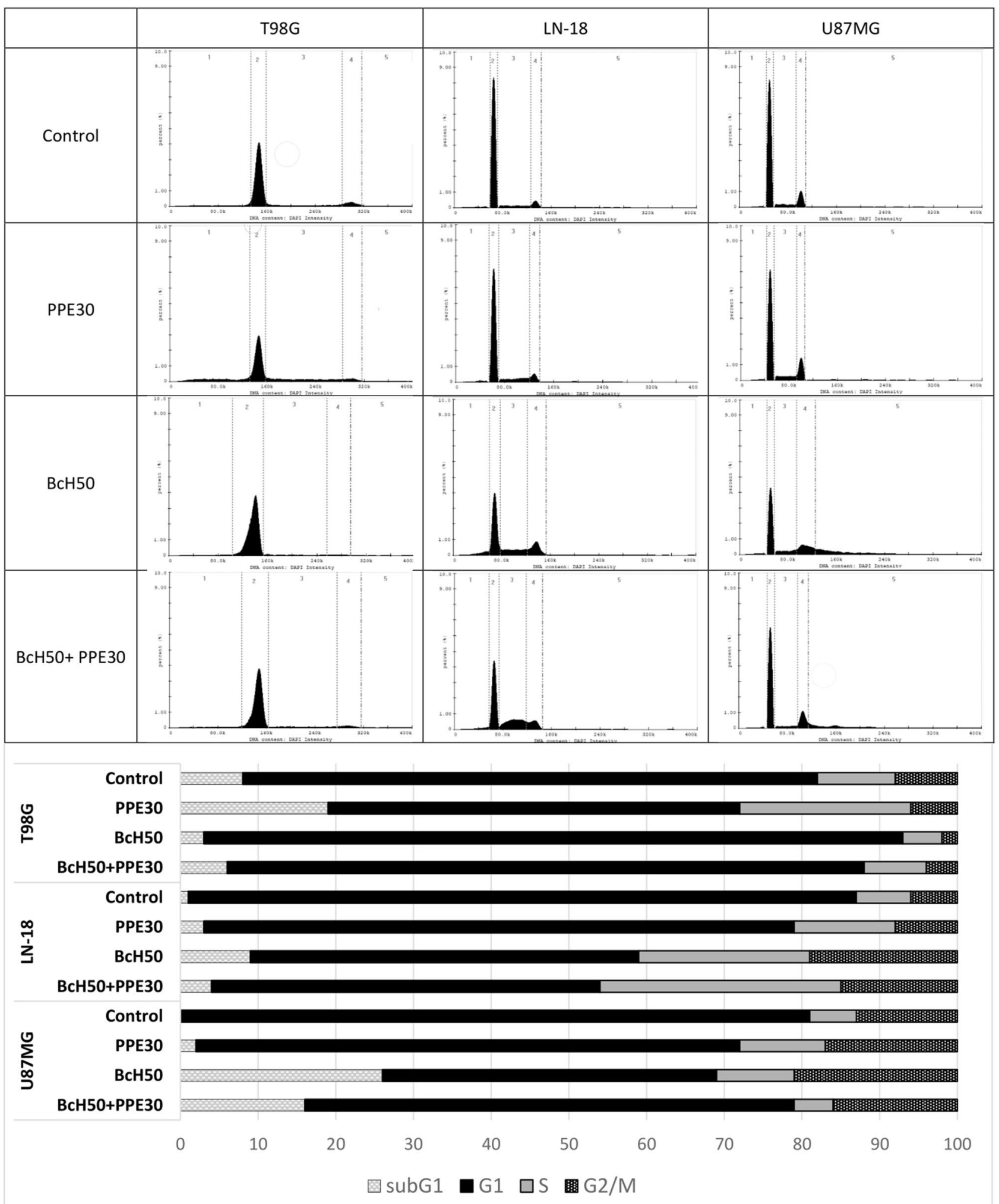

Figure 6. Cell cycle parameter analysis by flow cytometry. T98G, LN-18 and U87MG cells were incubated for $48 \mathrm{~h}$ with PPE30 $(30 \mu \mathrm{g} / \mathrm{mL}), \mathrm{BcH} 50(50 \mu \mathrm{g} / \mathrm{mL})$ and their combination compared to controls. Both the histogram (a) and the bars (b) present the distribution of cells in subG1 (1), G1 (2), S (3) and G2/M (4) phases of the cell cycle. 


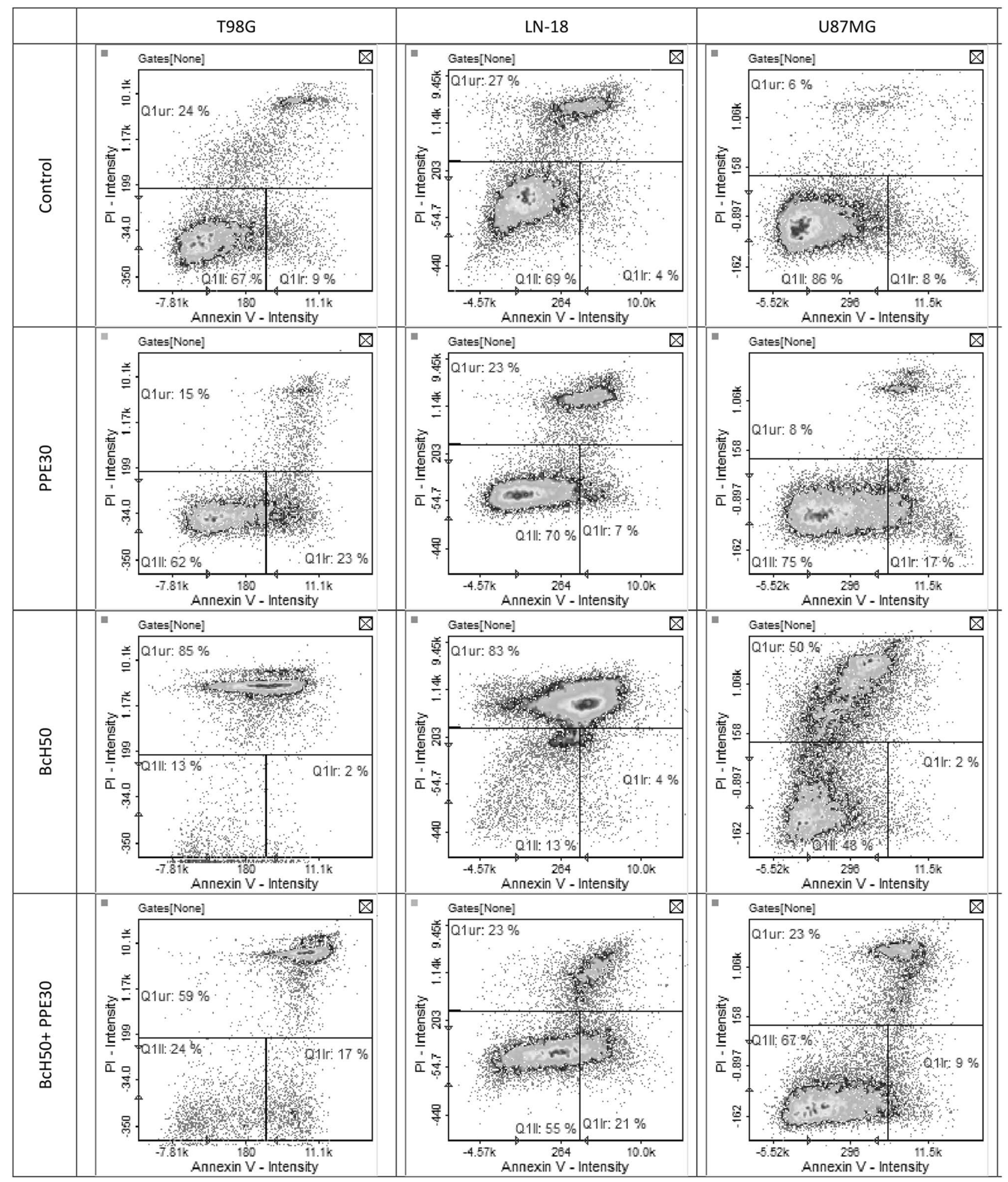

Figure 7. The quantitative assessment of T98G, LN-18 and U87MG cells apoptosis induced by PPE30 (30 $\mu \mathrm{g} /$ $\mathrm{mL}), \mathrm{BcH} 50(50 \mu \mathrm{g} / \mathrm{mL})$ and their combination using Annexin V/PI staining.

in the percentage of early and late apoptotic cells; in contrast, for SW480, SW620 and HCT116 cells, this marked increase occurred at a lower dose of bacopaside $\mathrm{II}^{41}$.

Our data showed a strong cooperative effect of propolis PPE30 and BcH50 on the studied human glioblastoma cell lines (T98G, LN-18, and U87MG cells). The inhibition of viability of the study glioma cells after incubation with the combination of PPE30 and $\mathrm{BcH} 50$ was significantly higher than that of these two extracts separately. The impact of PPE30 and BcH50 on DNA biosynthesis was examined by the $\left[{ }^{3} \mathrm{H}\right]$-thymidine incorporation 
assay to confirm that inhibition of viability was caused by a reduction in proliferation capacity. We found that the combination of PPE30 and $\mathrm{BcH} 50$ was more powerful in inhibiting proliferation (up to 13\%) than PPE30 or $\mathrm{BcH} 50$ alone (up to $67 \%$ and up to $47 \%$, respectively).

The combination of PPE30 and BcH50 increased the percentage of cells arrested at subG1 phase by approximately $3 \%$ (LN-18) and 16\% (U87MG); the percentage of cells arrested at G1 phase by approximately $8 \%$ (T98G); the percentage of cells arrested at S phase by approximately $24 \%(\mathrm{LN}-18)$; and the percentage of cells arrested at G2/M phase by approximately $9 \%$ (LN-18) and 3\% (U87MG) compared to the control. Moreover, the combination showed an effect on the induction of early apoptosis and late apoptosis/necrosis in the tested cell lines. The extract blend increased the ratio of T98G, LN-18 and U87MG cells in early apoptosis by approximately $8 \%, 17 \%$ and $1 \%$, respectively. Moreover, the number of cells in late apoptosis/necrosis increased by $35 \%$ and $17 \%$ in the T98G and U87MG cell lines, respectively.

The mechanism of action of $B$. monnieri is probably related to the ability of bacoside A to bind to the CaMK2A enzyme, which induces phosphorylation and subsequently allows binding to ryanodine receptors located in endoplasmic reticulum membrane, which induce excessive calcium release. It leads to extensive fluid uptake via macropinocytosis and consequently causing swelling of the cell and trigger lysis. Propolis, as well as CAPE and chrysin, which are the main biologically active components of propolis, enhance the extrinsic pathway of apoptosis in cancer cells stimulated by TRAIL, tumour necrosis factor (TNF) or Fas receptors. CAPE, through activation of p38, mitogen-activated protein kinase (MAPK), c-Jun N-terminal kinase (JNK), and extracellular signal-regulated (ERK) kinases, confirms the involvement of the intrinsic pathway of apoptosis in the mechanism of anticancer activity. The suppression of anti-apoptotic proteins (IAP), cellular FLICE-inhibitory protein (c-FLIP), B-cell lymphoma 2 (Bcl-2), phosphatidylinositol 3-kinase (PI3K/Akt) kinase and inhibition of NF-kB activity by chrysin have also been reported ${ }^{42}$.

In summary, these results are the first to show that extracts from Polish propolis combined with B. monnieri have strong cytotoxic and antiproliferative effects on human glioblastoma cell lines. The activity may be associated with the high content of both polyphenolic compounds in propolis and bacosides in B. monnieri. These findings suggest that propolis in combination with $B$. monnieri shows promising anticancer activity for the treatment of glioblastoma cancer. However, further studies are still required.

\section{Materials and methods}

Chemicals and reagents. Dulbecco's modified Eagle's medium (DMEM), Eagle's minimal essential medium (MEM) with L-glutamine (292 mg/L), heat-inactivated fetal bovine serum (FBS), trypsin-EDTA, penicillin, and streptomycin were purchased from PAA Laboratories GmbH (Pasching, Austria); calcium-free phosphate buffered saline (PBS) was obtained from BIOMED (Lublin, Poland). Bis(trimethylsilyl)trifluoroacetamide (BSTFA) with the addition of 1\% trimethylchlorosilane, alkane standard solutions C8-C20 and C21-C40, Folin-Ciocalteau reagent, methylthiazolyl diphenyl-tetrazolium bromide (MTT), dimethyl sulfoxide (DMSO), pyridine, sodium dodecyl sulfate solution, trichloroacetic acid, and (tris(hydroxymethyl) aminomethane hydrochloride) were obtained from Sigma-Aldrich (St. Louis, MO, USA). Ethanol at 95\% was obtained from the AWW Group (Kalisz, Poland), and sodium carbonate $\left(\mathrm{Na}_{2} \mathrm{CO}_{3}\right)$ was obtained from POCH (Gliwice, Poland). The scintillation cocktail was purchased from PerkinElmer (Boston, MA, USA). Methyl- ${ }^{3} \mathrm{H}$ thymidine was from MP Biomedicals, Inc. (Irvine, CA, USA). Bacoside A3 and bacoside A contain mixture bacoside A3, bacopaside II, bacopaside X, and bacopasaponin C were obtained from Sigma-Aldrich (St. Louis, MO, USA). Bacopasaponin C was purchased from Cayman Chemical Company (Ann Arbor, MI, USA). Luteolin and apigenin (purity $>96 \%$ ) were isolated from inflorescences of A. tomentosum ${ }^{43}$. Acetonitrile Optima was purchased from Fisher Chemical (Thermo Fisher Scientific, Leicestershire, UK), and ultra-pure water (resistivity of $18.2 \mathrm{M} \Omega$-cm) was obtained using the POLWATER DL3-100 system (Labopol, Kraków, Poland). Formic acid (Ph. Eur., Merck, Darmstadt, Germany) was used as the mobile phase modifier. Sodium sulfate buffer (0.05 M) (J.T. Backer, Deventer, Holland) prepared in ultra-pure water and adjusted to $\mathrm{pH} 2.3$ with dilute sulphuric acid (P.P.H. Stanlab, Lublin, Poland) using HANNA Instruments $\mathrm{pH}$ meter (model edge, Woonsocket, RI, USA). All solutions were filtered through a $0.45 \mathrm{~mm}$ pore size membrane filter using a Macherey-Nagel syringe filter (Düren, Germany).

Materials and extract preparation. B. monnieri extract $(\mathrm{BcH})$ was stated to contain $44 \mathrm{mg}$ of bacosides in one capsule (Hepatica, Niemce, Poland, batch no. 201605), and B. monnieri extract (BcS) BaCognize was stated to contain $30 \mathrm{mg}$ of bacosides in one capsule (Swanson Health Products, Fargo, North Dakota, USA, batch no. SWH145). Both were purchased as food supplement. However, only the inner contents were analyzed. Concentrated ethanolic extract containing 67\% Polish propolis was purchased from a manufacturer specializing in the production of apiculture product extracts from FINEX (Skawina, Poland, batch no. 150319). The solvent (95\% ethanol) was evaporated under reduced pressure at $38^{\circ} \mathrm{C}$ (Rotavapor R-3, Büchi, Flawil, Switzerland). The extract was lyophilized (Alpha 1-2 LD plus, Christ, Germany) before use and stored at $-20{ }^{\circ} \mathrm{C}$ for further use. Before in vitro analysis, $\mathrm{BcH}, \mathrm{BcS}$ and PPE were dissolved in DMSO and growth medium at a $1.0 \mathrm{mg} / \mathrm{mL}$ concentration as a stock solution. The final concentration of DMSO was $0.1 \%$.

GC-MS analysis of PPE. Five milligrams of PPE was diluted with $220 \mu \mathrm{L}$ of pyridine and $80 \mu \mathrm{L}$ of BSTFA with the addition of $1 \%$ trimethylchlorosilane. The reaction mixture was sealed and heated for $0.5 \mathrm{~h}$ at $60^{\circ} \mathrm{C}$ to form trimethylsilyl (TMS) derivatives. GC-MS analysis of PPE was performed using a GC-MS Clarus 680 gas chromatograph with a Clarus 600 T MS mass selective detector (PerkinElmer, Walthman, MA, USA) equipped with an Elie-5 MS fused silica column ( $30 \mathrm{~m}, 0.25 \mathrm{~mm}$ i.d., $0.25 \mathrm{~lm}$ film thickness) with electronic pressure control and a split/splitless injector. The helium flow rate through the column was $1 \mathrm{~mL} / \mathrm{min}$ in constant flow mode. The injector worked at $250^{\circ} \mathrm{C}$ in split (1:50) mode. The initial column temperature was $40{ }^{\circ} \mathrm{C}$, rising to $310{ }^{\circ} \mathrm{C}$ 
at $4{ }^{\circ} \mathrm{C} / \mathrm{min}$, and the higher temperature was maintained for $15 \mathrm{~min}$. The MSD detector acquisition parameters were as follows: transfer line temperature $280{ }^{\circ} \mathrm{C}$, MS source temperature $230{ }^{\circ} \mathrm{C}$ and MS quad temperature $150^{\circ} \mathrm{C}$. The EIMS spectrum was obtained at an ionization energy of $70 \mathrm{eV}$. The MSD was set to scan $41-600$ a.m.u. After integration, the fraction of each component in the total ion current was calculated. Linear temperature programmed retention indices $\left(\mathrm{I}_{\mathrm{T}}\right)$ were the components, and both mass spectral data and the calculated retention indices were used. The identification was considered reliable if the results of a computer search in the mass spectra library (NIST 98; NIST/EPA/NIH Library of Electron Ionization Mass Spectra) were confirmed by the experimental $\mathrm{I}_{\mathrm{T}}{ }^{\text {Exp }}$ values, i.e., if their deviation from the literature values $\mathrm{I}_{\mathrm{T}}{ }^{\text {Lit }}$ (NIST Chemistry WebBook, 2013) did not exceed \pm 7 u.i.

LC-ESI-MS analysis of BcH and BcS. The quality analysis was carried out according to the method described by Nuengchamnong N. et al. ${ }^{16}$ with some modifications. The screening of $\mathrm{BcH}$ and $\mathrm{BcS}$ extracts was performed on a 1260 Infinity LC (Agilent, Santa Clara, CA, USA) consisting of a binary pump, a column oven and photo-diode array (PDA) detector combined with 6230 LC/TOF (Agilent, Santa Clara, CA, USA) mass spectrometer equipped with an electrospray ionization (AJS-ESI). The separation was performed using a ZORBAX Eclipse Plus C18 column $(100 \times 4.6 \mathrm{~mm}, 3.5 \mu \mathrm{m})$ (Agilent, Santa Clara, CA, USA). The mobile phase were water (A) and acetonitrile (B), both with the addition of $0.1 \%$ formic acid. The separation was achieved by a gradient of $0-8 \min 35 \% \mathrm{~B}$; at $8-10$ min $35 \%-38 \% \mathrm{~B}$; $10-14 \min 38 \%-50 \% \mathrm{~B} ; 14-22$ min $50 \%-80 \%$ B; with next $5 \mathrm{~min}$ equilibration in the initial gradient. The flow rate was $0.6 \mathrm{~mL} / \mathrm{min}$ and the column temperature was maintained at $35 \pm 0.8^{\circ} \mathrm{C}$. The UV-Vis spectra was recorded from 190 to $540 \mathrm{~nm}$ with selective wavelength monitoring at $205 \mathrm{~nm}$. The MS parameters used for the ionization source were set as follows: drying and sheath gas flow: $10 \mathrm{~L} / \mathrm{min}$; nebulizer: $30 \mathrm{psi}$; source temperature $350{ }^{\circ} \mathrm{C}$; ion spray voltage $3500 \mathrm{~V}$ for the positive mode analysis. The data were collected in the $100-1200 \mathrm{~m} / \mathrm{z}$ range and processing was performed using the Mass Hunter Qualitative analysis software.

Quantitative assessment of saponins in $\mathrm{BcH}$ and BcS. The quantification was carried out according to the method described by Murthy et al. ${ }^{44}$ with some modifications. The contents of 3 capsules randomly selected from the package were mixed and homogenized. Fifty milligrams of the well-powdered sample was weighed and dissolved in a mixture of sodium sulfate buffer $\mathrm{pH} 2.3$ and acetonitrile (50:50, v/v) assisting ultrasound (Sonic-5, Polsonic, Poland) for $10 \mathrm{~min}$, filtered through a $0.45 \mathrm{~mm}$ filter, and made up to a final volume of $10 \mathrm{~mL}$. The sample was prepared in triplicate. Two standards (bacoside A3 and bacopasaponin C, $1 \mathrm{mg} /$ $\mathrm{mL}$ ) in five levels were used to prepare the calibration curve in the range of $10-100 \mu \mathrm{g} / \mathrm{mL}$. The calibration curve was calculated from the peak areas under the peak and presented as square equation regression (bacoside $A 3, R^{2}=0.9999, y=7.2171 x+10.604$; bacopasaponin $C, R^{2}=0.9999, y=8.2336 x+12.239$ ). Quantity assessment was performed on the same 1260 Infinity LC system (Agilent, Santa Clara, CA, USA) equipped with ZORBAX SB-C18 column $(250 \times 4.6 \mathrm{~mm}, 5 \mu \mathrm{m})$ protected by a security column guard ZORBAX SB-C18 $(12.5 \times 4.6,5 \mu \mathrm{m})$. The total analysis time was $75 \mathrm{~min}$. The mobile phase was a mixture of sodium sulfate buffer $(0.05 \mathrm{M})$ with $\mathrm{pH}$ 2.3 and acetonitrile in isocratic (68.5:38.5). Flow rate was set at $1 \mathrm{~mL} / \mathrm{min}$, selective wave length at $205 \mathrm{~nm}$, and volume of injection was set at $20 \mu \mathrm{L}$.

Total phenolic content (TPC) analysis. TPC was measured using the Folin-Ciocalteu colorimetric method. Twenty milligrams of $\mathrm{BcH}, \mathrm{BcS}$ and PPE was dissolved in $10 \mathrm{~mL}$ of $95 \%$ ethanol and centrifuged (5 min, $200 \mathrm{rpm}$ ). Then, $0.25 \mathrm{~mL}$ of the supernatants was shaken for $5 \mathrm{~min}$ with $1.25 \mathrm{~mL}$ of $0.2 \mathrm{M}$ Folin-Ciocalteau reagent, and after adding $1 \mathrm{~mL}$ of $7.5 \mathrm{~g} / \mathrm{L}$ sodium carbonate $\left(\mathrm{Na}_{2} \mathrm{CO}_{3}\right)$, the samples were incubated for $2 \mathrm{~h}$ at room temperature. The absorbances, in reference to the prepared blank, were read at $760 \mathrm{~nm}$ using a Cintra 3030 spectrophotometer (GBC Scientific Equipment, Braeside, Australia). The results were expressed as milligrams of gallic acid equivalent (GAE) per gram of dry extract. Assays were carried out in triplicate. Data are expressed as the mean $\pm \mathrm{SD}$.

Cell culture. The study was performed using three human glioblastoma cell lines (T98G, LN-18, and U87MG) obtained from the American Type Culture Collection (ATCC, Rockville, MD, USA). The cells were cultured in a humidified incubator at $37^{\circ} \mathrm{C}$ and $5 \% \mathrm{CO}_{2}$ atmosphere in the growth medium - MEM (U98MG, T98G) or DMEM (LN-18) supplemented with $10 \%$ heat-inactivated FBS and $100 \mathrm{U} / \mathrm{mL}$ penicillin and $0.1 \mathrm{mg} /$ $\mathrm{mL}$ streptomycin. Cell cultures were used between IX and XIV passages. Each experiment was performed in triplicate and repeated at least three times.

Cytotoxicity assay. Cell viability was measured using the MTT assay as previously described for glioma cells ${ }^{15}$. The effect of $\mathrm{BcH}$ and $\mathrm{BcS}$ extracts and their combination with PPE30 $(30 \mathrm{mg} / \mathrm{mL})$ on human glioblastoma cell lines (T98G, LN-18, U87MG) was studied after $24 \mathrm{~h}, 48 \mathrm{~h}$ and $72 \mathrm{~h}$ of treatment. The cells were cultured in a humidified incubator at $37^{\circ} \mathrm{C}$ in a 5\% $\mathrm{CO}_{2}$ atmosphere in MEM (T98G, U87MG) and DMEM (LN-18) supplemented with $10 \%$ heat-inactivated FBS, $100 \mathrm{U} / \mathrm{mL}$ penicillin and $0.1 \mathrm{mg} / \mathrm{mL}$ streptomycin. The study dose of propolis was selected in our earlier experiments ${ }^{14}$. The cells were seeded into 96 -well plates in a volume of 200 $\mu \mathrm{L}$ per well at a density of $1 \times 10^{5}$ cells $/ \mathrm{mL}$ and grown for $22 \mathrm{~h}$ at $37^{\circ} \mathrm{C}$ in a humidified $5 \% \mathrm{CO}_{2}$ incubator. The data are expressed as a percentage of the control (0.1\% DMSO).

DNA synthesis assay. $\quad\left[{ }^{3} \mathrm{H}\right]$-thymidine assays were performed to study DNA synthesis in the cells after treatment according to the protocol described in our previous study ${ }^{15}$. The cells were seeded $\left(1.5 \times 10^{5}\right.$ cell/well $)$ 
in 24-well plates in MEM or DMEM with $10 \%$ heat-inactivated FBS and exposed to the treatment medium containing DMSO $(0.1 \%$ - control), BcH $(25,50 \mu \mathrm{g} / \mathrm{mL}), \mathrm{BcS}(25,50 \mu \mathrm{g} / \mathrm{mL}), \mathrm{PPE}(30 \mu \mathrm{g} / \mathrm{mL})$ and their combination. The cells were cultured for $44 \mathrm{~h}$ prior to adding $0.5 \mu \mathrm{Ci}$ of $\left[{ }^{3} \mathrm{H}\right]$-thymidine per well. After $4 \mathrm{~h}$ of incubation, the medium was removed, and the cells were washed twice with cold $0.05 \mathrm{M}$ tris(hydroxymethyl) aminomethane hydrochloride and 5\% trichloroacetic acid, then lysed with $1 \%$ sodium dodecyl sulfate solution, scraped and transferred to a scintillation cocktail. The level of $\left[{ }^{3} \mathrm{H}\right]$-thymidine incorporated in the newly synthesized DNA strand was assessed by a scintillation counter in relation to cells proliferating during the $\mathrm{S}$ phase of the cell cycle.

Cell cycle assay. The impact of BcH50, PPE30 and the BcH50+ PPE30 mixture on the cell cycle was analyzed by the advanced image cytometer NucleoCounter NC-3000 (ChemoMetec, Lillerød, Denmark). The T98G, LN-18 and U87MG cells were seeded into 6-well plates at a density of $1 \times 10^{6}$ cells per well. After 24 h of incubation, cells were treated with $\mathrm{BcH} 50$, PPE30 and BcH50 + PPE30 mixture. After $48 \mathrm{~h}$ of cell treatment, the test was performed according to the 2-step cell cycle assay protocol of the manufacturer (ChemoMetec, Lillerød, Denmark). Cellular fluorescence was measured at $365 \mathrm{~nm}$ and quantified. DNA content histograms were displayed on screen. Markers in the displayed histograms were used to demarcate cells in the different cell cycle stages. The results are presented as the percentages of the cells in different cell cycle phases: subG1, G1/G0, S or G2/M.

Annexin V assay. Indications of early apoptosis were detected by initially staining the cells with Annexin V and propidium iodide (PI) solution followed by flow cytometry analysis using NucleoCounter NC-3000 (ChemoMetec, Lillerød, Denmark). The T98G, LN-18 and U87MG cells were seeded into 6-well plates at a density of $1 \times 10^{6}$ cells per well, and after $24 \mathrm{~h}$ of incubation, the cells were treated with BcH50, PPE30 and BcH $+\mathrm{PPE}$ mixture. After $48 \mathrm{~h}$ of incubation with the studied agents, the assay was performed following the manufacturer's protocol for the Annexin V assay (ChemoMetec, Lillerød, Denmark). The cells were harvested using trypsin/ EDTA and centrifuged at $400 \mathrm{~g}$ for $5 \mathrm{~min}$, and the supernatant was rejected. The cells were suspended in $100 \mu \mathrm{L}$ of Annexin V binding buffer. Next, $2 \mu \mathrm{L}$ of Annexin V-CF488A conjugate and $2 \mu \mathrm{L}$ of solution containing Hoechst 33,342 were added. Then, samples were incubated at $37^{\circ} \mathrm{C}$ for $15 \mathrm{~min}$ using a heating block (TS-100, bioSan, Riga, Latvia). After incubation, the stained cells were centrifuged and washed twice with Annexin V binding buffer. Cell pellets were resuspended in $100 \mu \mathrm{L}$ of Annexin V binding buffer supplemented with solution containing PI and analyzed immediately. After image acquisition and analysis scatter plots showing information about Annexin V-CF488A and propidium iodide fluorescence intensity, it was possible to determine the ratio of apoptotic and late apoptotic/necrotic cells. This test determined cell death via apoptotic or necrotic pathways. Normal living cells (lower left quadrant) were negatively stained for Annexin V-FITC and PI, and cells in early apoptosis (lower right quadrant) were positively stained with Annexin V-FITC and negatively with PI. Late apoptotic cells (upper quadrant) were positively stained with Annexin V-FITC and PI, and necrotic cells (upper quadrant) were negatively stained with Annexin V-FITC and positively with PI.

Statistical analysis. All data were analyzed using Dell Inc. (2016) Dell Statistica (data analysis software system), version 13 (software.dell.com). The results were expressed as the mean \pm SD and statistically compared to the control. Values were tested for normal distribution using the Shapiro-Wilk test. The differences between two groups were analyzed by Student's $t$ test. A $p$ value $<0.05$ was considered statistically significant.

Received: 7 January 2020; Accepted: 17 November 2020

Published online: 03 December 2020

\section{References}

1. Sasmita, A. O., Wong, Y. P. \& Ling, A. P. K. Biomarkers and therapeutic advances in glioblastoma multiforme. Asia Pac. J. Clin. Oncol. 14, 40-51. https://doi.org/10.1111/ajco.12756 (2018).

2. Ohka, F., Natsume, A. \& Wakabayashi, T. Current trends in targeted therapies for glioblastoma multiforme. Neurol. Res. Int. 2012, 878425. https://doi.org/10.1155/2012/878425 (2012).

3. Thakkar, J. P. et al. Epidemiologic and molecular prognostic review of glioblastoma. Cancer Epidemiol. Biomarkers Prev. 23, 1985-1996. https://doi.org/10.1158/1055-9965.EPI-14-0275 (2014).

4. Molassiotis, A., Fernadez-Ortega, P., Pud, D., Ozden, G. \& Scott, J. A. Use of complementary and alternative medicine in cancer patients: a European survey. Ann. Oncol. 16, 655-663. https://doi.org/10.1093/annonc/mdil10 (2005).

5. Markiewicz-Żukowska, R. et al. Ethanolic extract of propolis, chrysin, CAPE inhibit human astroglia cells. Adv. Med. Sci. 57, 208-216. https://doi.org/10.2478/v10039-012-0042-6 (2012).

6. Isidorov, V. A., Szczepaniak, L. \& Bakier, S. Rapid GC/MS determination of botanical precursors of Eurasian propolis. Food Chem. 142, 101-106. https://doi.org/10.1016/j.foodchem.2013.07.032 (2014).

7. Nina, N. et al. Antibacterial activity, antioxidant effect and chemical composition of propolis from the Región del Maule, central Chile. Molecules 20, 18144-18167. https://doi.org/10.3390/molecules201018144 (2015).

8. Bueno-Silva, B. et al. Brazilian red propolis attenuates inflammatory signaling cascade in LPS-activated macrophages. PLoS ONE 10, e0144954. https://doi.org/10.1371/journal.pone.0144954 (2015).

9. Demir, S. et al. Antiproliferative and proapoptotic activity of Turkish propolis on human lung cancer cell line. Nutr. Cancer 68, 165-172. https://doi.org/10.1080/01635581.2016.1115096 (2016).

10. Salim, E. I., Abd El-Magid, A. D., Farara, K. M. \& Maria, D. S. Antitumoral and antioxidant potential of Egyptian propolis against the PC3 prostate cancer cell line. Asian Pac. J. Cancer Prev. 16, 7641-7651. https://doi.org/10.7314/apjcp.2015.16.17.7641 (2015).

11. Jin, U. H. et al. Caffeic acid phenethyl ester induces mitochondria-mediated apoptosis in human myeloid leukemia U937 cells. Mol. Cell. Biochem. 310, 43-48. https://doi.org/10.1007/s11010-007-9663-7 (2008).

12. Umthong, S., Phuwapraisirisan, P., Puthong, S. \& Chanchao, C. In vitro antiproliferative activity of partially purified Trigona laeviceps propolis from Thailand on human cancer cell lines. BMC Complement. Altern. Med. 11, 37. https://doi.org/10.1186/14726882-11-37 (2011).

13. Elnakady, Y. A. et al. Characteristics, chemical compositions and biological activities of propolis from Al-Bahah, Saudi Arabia. Sci. Rep. 7, 41453. https://doi.org/10.1038/srep41453 (2017). 
14. Markiewicz-Żukowska, R. et al. Propolis changes the anticancer activity of temozolomide in U87MG human glioblastoma cell line. BMC Complement. Altern. Med. 13, 50. https://doi.org/10.1186/1472-6882-13-50 (2013).

15. Borawska, M. H. et al. Anti-proliferative and anti-migration effects of Polish propolis combined with Hypericum perforatum L. on glioblastoma multiforme cell line U87MG. BMC Complement. Altern. Med. 16, 367. DOI: https://doi.org/https://doi.org/10.1186/ s12906-016-1351-2 (2016).

16. Nuengchamnong, N., Sookying, S. \& Ingkaninan, K. LC-ESI-QTOF-MS based screening and identification of isomeric jujubogenin and pseudojujubogenin aglycones in Bacopa monnieri extract. J. Pharm. Biomed. Anal. 129, 121-134. https://doi.org/10.1016/j. jpba.2016.06.052 (2016).

17. Pawar, R. S. \& Bhutan, K. K. New dammarane triterpenoidal saponins from Bacopa monniera. Indian J. Chem. 45B, 1511-1514 (2006).

18. Zhou, Y., Shen, Y. H., Zhang, C. \& Zhang, W. D. Chemical constituents of Bacopa monnieri. Chem. Nat. Compd. 43, 355-357. https ://doi.org/10.1007/s10600-007-0133-y (2007).

19. Bhandari, P., Kumar, N., Singh, B. \& Kaul, V. K. Bacosterol glycoside, a new 13, 14-seco-steroid glycoside from Bacopa monnieri. Chem. Pharm. Bull. (Tokyo) 54, 240-241. https://doi.org/10.1248/cpb.54.240 (2006).

20. Bhattacharya, S. K. \& Ghosal, S. Anxiolytic activity of a standardized extract of Bacopa monniera: an experimental study. Phytomedicine 5, 77-82. https://doi.org/10.1016/S0944-7113(98)80001-9 (1998).

21. Subashri, B. \& Koilpillai, Y. J. Phytochemical analysis and in vitro antioxidant activity from the extract of Bacopa monnieri (L.) Pennell-a multipurpose medicinal plant. Int. J. Pharm. Biol. Sci. 3, 698-702 (2012).

22. Viji, V. \& Helen, A. Inhibition of pro-inflammatory mediators: role of Bacopa monnieri (L.) Wettst. Inflammopharmacology 19, 283-291. https://doi.org/10.1007/s10787-010-0046-4 (2011).

23. Jyoti, A. \& Sharma, D. Neuroprotective role of Bacopa monnieri extract against aluminium-induced oxidative stress in the hippocampus of rat brain. Neurotoxicology 27, 457-457. https://doi.org/10.1016/j.neuro.2005.12.007 (2006).

24. Gudipati, T., Srivastava, P. L., Bhadauria, R. \& Prasad, G. B. Hepatoprotective potential of in vitro Bacopa monnieri L. against carbon tetrachloride - induced hepatotoxicity in albino mice. Int. J. Pharm. Biol. Sci. 3, 664-672 (2012).

25. Ravikumar, S., Nazar, S., Nuralshiefa, A. \& Abideen, S. Antibacterial activity of traditional therapeutic coastal medicinal plants against some pathogens. J. Environ. Biol. 26, 383-386 (2005).

26. Sairam, L., Rao, C., Babu, M. \& Goel, R. K. Prophylactic and curative effects of Bacopa monniera in gastric ulcer models. Phytomedicine 8, 423-430. https://doi.org/10.1078/S0944-7113(04)70060-4 (2001).

27. Aithal, M. G. S. \& Rajeswari, N. Bacoside A induced sub-G0 arrest and early apoptosis in human glioblastoma cell line U-87 MG through notch signaling pathway. Brain Tumor Res. Treat 7, 25-32. https://doi.org/10.14791/btrt.2019.7.e21 (2019).

28. Popova, M., Silici, S., Kaftanoglu, O. \& Bankova, V. Antibacterial activity of Turkish propolis and its qualitative and quantitative chemical composition. Phytomedicine 12, 221-228. https://doi.org/10.1016/j.phymed.2003.09.007 (2005).

29. Popova, M. et al. Characterization and biological evaluation of propolis from Poland. Molecules 22, E1159. https://doi.org/10.3390/ molecules22071159 (2017).

30. Isidorov, V. A., Bakier, S., Pirożnikow, E., Zambrzycka, M. \& Swiecicka, I. Selective behaviour of honeybees in acquiring European propolis plant precursors. J. Chem. Ecol. 42, 475-485. https://doi.org/10.1007/s10886-016-0708-9 (2016).

31. Bankova, V., Popova, M., Bogdanov, S. \& Sabatini, A. G. Chemical composition of European propolis: expected and unexpected results. Z. Naturforsch. 57C, 530-533. https://doi.org/10.1515/znc-2002-5-622 (2002).

32. Wieczynska, A. et al. Antimicrobial activity, cytotoxicity and total phenolic content of different extracts of propolis from the west pomeranian region in Poland. Acta Pol. Pharm. 74, 715-722 (2017).

33. Borges, K. S., Brassesco, M. S., Scrideli, C. A., Soares, A. E. \& Tone, L. G. Antiproliferative effects of Tubi-bee propolis in glioblastoma cell lines. Genet. Mol. Biol. 34, 310-314. https://doi.org/10.1590/s1415-47572011000200024 (2011).

34. Szliszka, E. et al. Ethanolic extract of propolis (EEP) enhances the apoptosis- inducing potential of TRAIL in cancer cells. Molecules 14, 738-754. https://doi.org/10.3390/molecules14020738 (2009).

35. Szliszka, E. \& Krol, W. Polyphenols isolated from propolis augment TRAIL-induced apoptosis in cancer cells. Evid. Based Complement. Alternat. Med. 2013, 731940. https://doi.org/10.1155/2013/731940 (2013).

36. Noureddine, H. et al. Chemical characterization and cytotoxic activity evaluation of Lebanese propolis. Biomed. Pharmacother. 95, 298-307. https://doi.org/10.1016/j.biopha.2017.08.067 (2017).

37. Jeyasri, R. et al. Bacopa monnieri and their bioactive compounds inferred multi-target treatment strategy for neurological diseases: a cheminformatics and system pharmacology approach. Biomolecules 10, 1-19. https://doi.org/10.3390/biom10040536 (2020).

38. Chaudhari, K. S., Tiwari, N. R., Tiwari, R. R. \& Sharma, R. S. Neurocognitive effect of nootropic drug Brahmi (Bacopa monnieri) in Alzheimer's disease. Ann. Neurosci. 24, 111-122. https://doi.org/10.1159/000475900 (2017).

39 John, S., Sivakumar, K. C. \& Mishra, R. Bacoside A induces tumor cell death in human glioblastoma cell lines through catastrophic micropinocytosis. Front. Mol. Neurosci. 10, 171. https://doi.org/10.3389/fnmol.2017.00171 (2017).

40. Mallick, M. N. et al. Exploring the cytotoxic potential of triterpenoids-enriched fraction of Bacopa monnieri by implementing in vitro, in vivo, and in silico approaches. Pharmacogn. Mag. 13(Suppl), S595-606. https://doi.org/10.4103/pm.pm_397_16 (2017).

41. Smith, E. et al. The purified extract from the medicinal plant Bacopa monnieri, bacopaside II, inhibits growth of colon cancer cells in vitro by inducing cell cycle arrest and apoptosis. Cells https://doi.org/10.3390/cells7070081 (2018).

42. Sawicka, D. et al. The anticancer activity of propolis. Folia Histochem. Cytobiol. 50, 25-37. https://doi.org/10.5603/FHC.2012.0004 (2012).

43. Strawa, J. et al. Phytochemical examination of woolly burdock Arctium tomentosum leaves and flower heads. Chem. Nat. Compd. 56, 345-347. https://doi.org/10.1007/s10600-020-03027-w (2020).

44. Murthy, P. B. S. et al. Estimation of twelve bacopa saponins in Bacopa monnieri extracts and formulations by high-performance liquid chromatography. Chem. Pharm. Bull. 54, 907-911. https://doi.org/10.1248/cpb.54.907 (2006).

\section{Acknowledgements}

This work was supported by Medical University of Bialystok (Poland) in Grants Numbered N/ST/ $\mathrm{MN} / 18 / 005 / 2216$ and N/ST/ZB/17/007/2216. The scientific team was responsible for all stages of the study (design, methodology, analysis, interpretation of the data and writing the manuscript).

\section{Author contributions}

J.M. and S.K.N. were responsible for conception, study design, obtaining funds, laboratory analysis, statistical analysis and writing the manuscript. J.M. and K.J.G.K. performed G.C.-M.S. analysis and prepared Table 1 and Fig. 1. R.M.Ż., P.N. and K.J.G.K. performed laboratory analysis (TPC, cytotoxic activity, DNA synthesis, cell cycle, apoptosis quantification), data analysis and prepared Table 4 and Fig. 3-7. J.S. and M.T. carried out the LC-MS analysis and prepared the final version of the manuscript. J.S. and M.T. prepared Tables 2, 3 and Fig. 2. KS and MHB revised the manuscript critically for important intellectual content. All authors reviewed and approved the manuscript. 


\section{Competing interests}

The authors declare no competing interests.

\section{Additional information}

Correspondence and requests for materials should be addressed to R.M.

Reprints and permissions information is available at www.nature.com/reprints.

Publisher's note Springer Nature remains neutral with regard to jurisdictional claims in published maps and institutional affiliations.

(c) (1) Open Access This article is licensed under a Creative Commons Attribution 4.0 International License, which permits use, sharing, adaptation, distribution and reproduction in any medium or format, as long as you give appropriate credit to the original author(s) and the source, provide a link to the Creative Commons licence, and indicate if changes were made. The images or other third party material in this article are included in the article's Creative Commons licence, unless indicated otherwise in a credit line to the material. If material is not included in the article's Creative Commons licence and your intended use is not permitted by statutory regulation or exceeds the permitted use, you will need to obtain permission directly from the copyright holder. To view a copy of this licence, visit http://creativecommons.org/licenses/by/4.0/.

(c) The Author(s) 2020 